International Journal of Social Science And Human Research

ISSN(print): 2644-0679, ISSN(online): 2644-0695

Volume 04 Issue 11 November 2021

DOI: $10.47191 / \mathrm{ijsshr} / \mathrm{v} 4-\mathrm{i} 11-30$, Impact factor-5.586

Page No: 3284-3291

\title{
Second -Year English Majored Students' Perception of Possible Problems in Writing Essays
}

\author{
Nguyen Huynh Trang', Le Anh Khoa ${ }^{2}$ \\ ${ }^{1}$ School of Foreign Languages, UEH University, Vietnam \\ ${ }^{2}$ School of Foreign Languages, Tra Vinh University, Vietnam
}

\begin{abstract}
To acquire a language, learners need to be skillful at the four skills namely: listening, speaking, reading and writing. Among them, writing is usually considered a complex skill to learn. This study is aimed to investigate the second-year English majored students' perception of essay writing problems encountered and solutions to overcome these problems. The participants of this study are 44 second year English majored students at a public university in the Mekong Delta of Vietnam, consisting of 32 females and 12 males. The data were collected by a questionnaire to explore the difficulties encountered by EFL learners in writing essays and their expectations from their lecturers as well as from themselves to have better performance. The results revealed that students face major difficulties in writing essays including linguistic, psychological, cognitive factors. With the hope to get better writing performance, the students expected more assistance from their lecturers, including giving more feedbacks on their writing pieces, recommending appropriate reading materials and providing more grammar courses. They also admitted that their writing pieces will be improved when they themselves practice more such as forming their writing habits, gaining more vocabularies and self-editing or asking feedback from peers.
\end{abstract}

KEYWORDS: English majored students, Writing, Writing difficulties

\section{INTRODUCTION}

It is undeniable that English is used in a variety of professional fields such as business, medicine, science or diplomacy around the world. In the period of global integration, English is considered as an essential language in many countries where tourism has been developed such as Thailand, Indonesia and Vietnam. According to Hoang (2018), in the context of economic renovation and of the open-door policy, English becomes the first foreign language to be trained in Vietnam because frequent influxes of foreign business and tourism have increased. Besides, he claims that Vietnamese people need communication skills in English to get a better job not only in the tourism and hospitality but also in many other fields with the growth of international businesses and trades, and the increasing number of foreign tourists. English is taught in schools, in universities and in evening foreign language centers across the country. However, to have a good command in English language, learners need to be trained skillfully the four skills of language including listening, speaking, reading, and writing. Writing is a productive skill which language learner need much time to practice. Among the four skills, Mehrabi (2014) believes writing is the most critical skill to master in learning English. In the globalization era, many books, newspapers, letters, emails, and articles are written in English. In addition, writing in English is a task that is often required in university. Thus, having good writing English skills are important for a positive passing of university assignments. Unfortunately, most of the EFL learners struggle in improving writing skills especially in writing essays. In recent years, there have been countless studies conducted to explore the EFL students' problems in writing learning. In this study, we want to investigate the second-year English majors 'perception of the problems they face when writing essays and their proposed solutions to gain better performance in writing.

The following research questions have been established to enable the researchers to attain the objectives of the study:

1. What are the second-year English majored students' beliefs of the problems in writing essays?

2. What solutions do they perceive to have to overcome these difficulties?

\section{LITERATURE REVIEW}

\section{Definitions of Writing}

Writing is defined in different ways by numerous researchers. Firstly, writing is defined as the skill or activity of producing words on a surface by Cambridge Dictionary (2019). According to Ivanic (1988), writing is an act of identity in which people align themselves with socio-culturally shaped subject positions, and thereby play their part in reproducing or challenging dominant practices and discourses, and the values, beliefs, and interests which they embody. Besides, Nordquist 


\section{Second -Year English Majored Students' Perception of Possible Problems in Writing Essays}

(2017) described writing as a graphic symbol system that can be used to express information. Besides, Pratiwi (2012) reported that writing is a method of representing language in visual form. Writing systems use sets of symbols to represent the sounds of speech, and may also have symbols for such things as punctuation and numerals. Similarly, Rao and Durga (2018) claimed that writing is the system of written symbols, representing the sounds, syllables or words of the language, with different mechanisms capitalization, spelling and punctuation, word form and function.

In language education, Bowker (2007) assumes writing as a skill which is required in many contexts throughout life. For instance, you can write an email to a friend or reflect on what happened during the day in your personal diary.

In the current study, writing is considered a system of graphic symbols written or mark on a flat surface of some kind that can use to communicate. It is the system of written symbols, representing the sounds, syllables or words of the language, with different mechanisms - capitalization, spelling and punctuation, word form and function.

Writing difficulties

In the context of learning English as a Foreign language, writing is believed the hard skill to acquire. Researchers in the field of language have identified problems that students face in writing into three main categorizes as follows.

Linguistic Difficulties

Solikah (2017) found problems on linguistic factors in writing vary from simple to the complex ones. Besides, he has identified students faced essay writing problems in all aspects of linguistics factors including syntax, grammar, vocabulary, and mechanic. Besides, Rahmatunisa (2014) claimed that linguistics problems occur within structuring sentences such as tenses, word class, using articles, word formation, and word error. These problems typically can arise when ELF students transfer their ideas from native language - mother tongue into target language - English. According to Byrne (1988), the linguistic aspects including grammar, vocabulary, language use and choice of a sentence in writing must have fully monitored.

\section{Psychological Difficulties}

Nadjette (2016) claimed that the learner's psychology is a pivotal contributor to the success of a foreign language learning process. Attitudes, motivation, and anxiety are some psychological factors which would assist the success or lead to unconsciously built barriers that end with an evident failure in acquiring the necessary skills to achieve competence and proficiency in the English language.

\section{Cognitive Difficulties}

Alfaki (2015) found that some students' cognitive difficulties were punctuation, capitalization, spelling, content and organization problems. Similarly,Solikhah(2017) reported mechanics in writing refer to ways writers handle basic convention of writing, such as punctuation, spelling, and capitalization. The mechanical errors include punctuation errors, spelling errors, capitalization errors, paragraphing, and handwriting. Additionally, Rahmatunisa (2014) emphasized that cognitive problems relate to how to organize ideas, use punctuation, address a topic, follow a topic, and follow instructions and directions. Besides, Byrne (1988) claimed that writing has to be thought through formal instructions like spelling, punctuation, capitalization and paragraphing.

\section{Related studies}

Nyasimi (2014) handled a study into the topic "Challenges Students Face in Learning Essay Writing Skills in English in Secondary Schools in Manga District, Nyamira Country, Kenya". The study aimed to explore challenges students in secondary schools in Maga district encountered when learning to write essays in English language. The sample of the study was 180 students and 10 teachers of English language. A questionnaire for students, interviews with teachers and delivering an essay writing test for students were main instruments of the study. The research findings showed that teachers applied some methods such lecturing, questioning and demonstrating in conducting writing lessons. Further results related to challenges encountered in writing essays fell into some categories such as inadequate content mastery, incorrect use of grammar, first language interference, limited vocabulary, and inadequate teaching and learning resources. Additionally, the study results indicated that most of the students rarely employ interactive learning strategies in their writing lessons. Based the results, the researcher also gave some recommendations to curriculum developers, policy makers, teachers and students to better the teaching and learning second language writing skills.

Alfaki (2015) carried out a study entitled "University Students' English Writing Problems: Diagnosis \& Remedy". The study aimed at identifying students' writing problems in English and suggesting several ways to help them overcome these problems. The researcher mainly examined 20 English language students' compositions and explored several findings related to their problems. The results revealed that they encountered some problems such as morphological and syntactic problems, lacking of several writing development skills, cognitive problems and graphomotor problems. In light of these results, some recommendations have been made. When learners speak, they will make natural pauses and this will help them in punctuation. Spelling mistakes can be corrected by using dictionaries or spellcheckers. Usage mistakes and grammar mistakes will eventually disappear if the students read extensively in English.

Ariyanti and Firtriana (2017) had a survey about "ELF Students' Difficulties and Needs in Essay Writing". The study focused on investigating the difficulties faced by ELF students in essay writing as well as exploring their learning needs to have a better quality of English composition. The population of this study is 33 EFL students and a lecturer at Widya Gama Mahakam 


\section{Second -Year English Majored Students' Perception of Possible Problems in Writing Essays}

University. Examining essays and a questionnaire for students are two study instruments that support authors to analyze. For lecturers, a semi-structured interview was also conducted to collect lecturer 's perception related to challenging matters about teaching essay writing. The research findings showed that students have difficulties in grammatical, cohesion and coherence terms, paragraph organization, diction, and vocabulary, misspellings. Additionally, the students expected more intense guidance from the lecturer. Besides, the results from the interview illustrated that limited time and a big number of students in one class became lecturer's barriers to improve the students' essay. Hence, two possible suggestions were recommended for lecturer as follows guiding students properly using step-by-step procedures and explicit explanation related to the revision given is a need.

Belkhir and Benyelles (2017) conducted a study on "Identifying EFL Learners Essay Writing Difficulties and Sources: A Move toward Solution the Case of Second Year EFL Learners at Tlemcen University" and pointed out EFL learners essay writing difficulties. The questionnaire, interview, and students' finale essay writing drafts are three research instruments that help authors to gather and record data both quantitatively and qualitatively. The results showed that EFL learners meet difficulties in both coherence and cohesion due to the lack of reading, first language transfer, and low writing practice. From the findings above, the authors recommended that ELF students should build their reading and writing habits to write an effective essay.

Al-Mukdad (2019) investigated writing problems that students at Arab International University encountered when they are taking Academic Writing module. The study was conducted by using a questionnaire delivered to 50 students studying various majors at Arab International University. The results showed that the sample population agreed that they had problems with all aspects of writing. In particular, the study indicated that the participants encountered problems in revising their own writing products due to their low detection of their own mistakes. Other problems related to their ability to use correct grammatical and linguistic features. The students also admitted that they had low motivation of doing good writing. The study also suggested some applicable solutions to help the students better in their writing academic pieces.

\section{METHODOLOGY}

\section{Research design}

The present study was conducted to investigate what the second-year students majoring in English think of some difficulties that they face in writing essays and some solutions proposed by them to overcome their own difficulties to write effective essays. This study was designed as descriptive research with mixed methods including quantitative and qualitative methods.

Participants

This study was carried out with the participation of 44 students who responded the questionnaire and five students randomly selected from the sample joining the semi-structured interview. These students were in second-year and took the English major program at a public university in the Mekong Delta, Vietnam. The participants 'age ranges from 18 to 20 years old. The participants' English level is supposed to be intermediate. In these classes, the students were practice mainly with the book Final Draft by Lambert et al. (2016) published by Cambridge: Cambridge University Press.

\section{The research instruments}

To answer the research questions, the researchers employed a questionnaire including two sections. The first section asked about the demographic of the participants. The second part was designed based on the theoretical concepts and related studies which consisted of 43 items in five-point Likert scale, ranging from strongly disagree to strongly agree. This part aimed to explore the difficulties that the participants face when writing essays and what solutions they expect to tackle their problems.

Additionally, semi-structured interviews were conducted to gain insightful opinions of the participants' difficulties in writing essays and what they expect to solve their problems. The interviews were conducted with five random chosen students from the sample during their break time as informal talks so that the students could freely share their ideas.

\section{Data gathering procedure}

Data gathering procedure include four stages. The first stage is reviewing and designing the instruments. The second stage is piloting the questionnaire and the interview. The next one is delivering the questionnaire to 44 second-year students majoring in English and interviews some. Then, the collected data is analyzed by the researcher.

To identify the criterion of the mean score, we followed the scale proposed by Oxford (1990) as presented in Table 1 below.

Table 1. Key to understanding of mean scores

\begin{tabular}{ll}
\hline Mean score & Level \\
\hline 1.0 to 2.4 & Low \\
\hline 2.5 to 3.5 & Medium \\
\hline 3.6 to 4.4 & High \\
\hline 4.5 to 5.0 & Very high \\
\hline
\end{tabular}




\section{Second -Year English Majored Students' Perception of Possible Problems in Writing Essays}

\section{FINDINGS AND DISCUSSIONS}

\section{Questionnaire results}

To check the reliability of the questionnaire, a scale test was conducted and the results indicated that the instrument was reliable with significant high Cronbach's Alpha coefficient of .940 for 43 items in total.

The results from the questionnaire are divided into four categories namely linguistic, psychological, cognitive, and miscellaneous difficulties. The overall mean score of all four groups was illustrated in the following table.

Table 2: Descriptive Statistics of four categories of problems in essay writing

\begin{tabular}{llllll}
\hline & $\mathrm{N}$ & Minimum & Maximum & Mean & S.D \\
\hline Linguistic problems & 44 & 1.42 & 4.58 & 3.6 & .596 \\
\hline Psychological problems & 44 & 1.80 & 4.80 & 3.7 & .618 \\
\hline Cognitive problems & 44 & 1.00 & 4.60 & 3.5 & .720 \\
\hline Miscellaneous problems & 44 & 1.63 & 4.50 & 3.4 & .536 \\
\hline
\end{tabular}

Based on Oxford's scale (1990) and the results from the questionnaire presented in Table 2, it can be inferred that the second-year students majoring in English faced challenges in writing essays at medium level for the miscellaneous and cognitive groups ( $M=3.4$ and $M=3.5$ respectively) and at high level for linguistic and psychological types ( $M=3.6$ and $M=3.7$ respectively).

Linguistic problems

The problems in linguistic type which were found at high level $(\mathrm{M}=3.6)$ were analyzed more specific and illustrate in Table 3 below.

Table 3: Students' problems related to linguistic factors

\begin{tabular}{llllll}
\hline Have limited vocabulary & $\mathrm{N}$ & Min & Max & Mean & S.D \\
\hline Do not choose the correct words & 44 & 1 & 5 & 3.9 & 0.89 \\
\hline Forget spelling of the words I want to use & 44 & 2 & 5 & 3.8 & 0.77 \\
\hline Use wrong transitional words & 44 & 1 & 5 & 3.3 & 1.04 \\
\hline Use wrong linking words & 44 & 1 & 5 & 3.4 & 1.13 \\
\hline Use the informal, conversational language & 44 & 1 & 5 & 3.1 & 1.15 \\
\hline Use wrong structures & 44 & 1 & 5 & 3.8 & 0.84 \\
\hline Use simple structures & 44 & 2 & 5 & 3.8 & 0.68 \\
\hline Use the wrong verb tenses & 44 & 1 & 5 & 3.7 & 1.02 \\
\hline Have fragment sentences & 44 & 1 & 5 & 3.3 & 0.99 \\
\hline Lack of topical knowledge & 44 & 1 & 5 & 3.4 & 1.02 \\
\hline Translate from mother tongue to English language & 44 & 1 & 5 & 3.7 & 1.01 \\
\hline
\end{tabular}

Among the twelve items, lacking vocabulary $(\mathrm{M}=3.9, \mathrm{SD}=.89)$ in writing essays is found the biggest problem faced by the participants. Besides, majority of second-year English majors admitted that they frequently chose incorrect words $(\mathrm{M}=3.8, \mathrm{SD}=$ .76), used informal language $(\mathrm{M}=3.8, \mathrm{SD}=.84)$ and wrong structures $(\mathrm{M}=3.8, \mathrm{SD}=.68)$ which were ranked the second. Additionally, using simple structures $(\mathrm{M}=3.7, \mathrm{SD}=1.02)$ and translating from the mother tongue to the English language $(\mathrm{M}=3.7$, $\mathrm{SD}=1.01$ ) were the next problems which make the participants' writing pieces of essays were assessed low by their teachers.

The findings in Table 2 indicate that the second-year English majors often faced several problems related to vocabulary issues when writing essays including lacking vocabulary, choosing the incorrect words and using the informal language, which are in line with those found by Ariyanti and Firtriana (2017). Besides, some students also encountered grammar difficulties including using wrong structures, using simple structures which are in accord with the studies of Ariyanti and Firtriana (2017), Belkhir and Benyelles (2017).

\section{Psychological difficulties}

The second type of problems which student participants face when writing essays belongs to psychological factors. The results are displayed in Table 3 below. 


\section{Second -Year English Majored Students' Perception of Possible Problems in Writing Essays}

Table 4: Students' problems related to psychological factors

\begin{tabular}{llllll}
\hline & $\mathrm{N}$ & Min & Max & Mean & S.D \\
\hline Write under time pressure & 44 & 1.00 & 5.00 & 3.7 & .97 \\
\hline Be under pressure of other courses & 44 & 1.00 & 5.00 & 3.8 & .84 \\
\hline Don't have motivation to write & 44 & 1.00 & 5.00 & 3.7 & .97 \\
\hline Fear of negative feedback from instructors & 44 & 1.00 & 5.00 & 3.5 & .88 \\
\hline Don't feel self-confident about writing skills & 44 & 1.00 & 5.00 & 3.8 & .98 \\
\hline
\end{tabular}

Table 4 shows that of all the problems related to psychological factors, being under pressure of other courses $(\mathrm{M}=3.8, \mathrm{SD}=.84)$ and not feeling self-confident about writing skills $(\mathrm{M}=3.8, \mathrm{SD}=.98)$ were two most popular psychological difficulties faced by second-year English majors. Additionally, they believe that being under time pressure $(\mathrm{M}=3.7, \mathrm{SD}=.97)$ and not having the motivation to write $(\mathrm{M}=3.7, \mathrm{SD}=.97)$ were factors which affect their writing proficiency.

\section{Cognitive difficulties}

It can be seen from Table 5 below, second-year English majors perceived they have a few problems related to cognitive factors. The participants reckoned that they do not have ideas to write the content which received highest agreement of the participants $(\mathrm{M}=3.8, \mathrm{SD}=.97)$. Organization and form of essays sometimes challenged these participants $(\mathrm{M}=3.5, \mathrm{SD}=.89)$. However, other items related to mechanical errors seem to be less challenging to them with lower mean scores (M=3.2).

Table 5: Students' problems related to cognitive factors

\begin{tabular}{lccccc}
\hline & $\mathrm{N}$ & Min & Max & Mean & S.D \\
\hline Don't use punctuation correctly & 44 & 1.00 & 5.00 & 3.2 & 1.13 \\
\hline Don't capitalize properly & 44 & 1.00 & 5.00 & 3.2 & 1.09 \\
& & & & & \\
\hline Write the wrong words' spelling & 44 & 1.00 & 5.00 & 3.4 & .95 \\
\hline Don't have many ideas to write & 44 & 1.00 & 5.00 & 3.8 & .97 \\
\hline Organization and form of the essays & 44 & 1.00 & 5.00 & 3.6 & .89 \\
\hline
\end{tabular}

The results from Table 5 also pointed out that the English major sophomores also face cognitive problems in writing essays but this category seems to be less challenging. It is clear that the participants usually don't have many ideas to write their essays. Besides, organization and form of essays challenge them. The results are consistent with most of previous studies (Alfaki, 2015; Ariyanti \& Firtriana, 2017; Belkhir \& Benyelles, 2017).

\section{Miscellaneous difficulties}

Table 6 below shows that lacking of ideas to illustrate or to explain supporting ideas in the essays $(\mathrm{M}=3.8, \mathrm{SD}=.83)$ came the first on the list of the items and lacking writing development skills $(\mathrm{M}=3.7, \mathrm{SD}=.83)$ was the second rank. Besides, students agreed that they sometimes do not know how to write a thesis statement $(M=3.5, S D=.95)$, do not feel interested in the topics $(M=$ $3.4, \mathrm{SD}=1.06)$, and do not know how to write the topic sentences for the body paragraphs $(\mathrm{M}=3.4, \mathrm{SD}=1.01)$.

Table 6: Students' problems related to miscellaneous factors

\begin{tabular}{|c|c|c|c|c|}
\hline $\mathrm{N}$ & Min & Max & Mean & S.D \\
\hline Lack writing development skills & 2.00 & 5.00 & 3.7 & .83 \\
\hline Go off the topic & 1.00 & 5.00 & 3.3 & .83 \\
\hline Don't get enough feedback from the teachers & 1.00 & 5.00 & 3.0 & .99 \\
\hline Don't feel interested in the writing topics & 1.00 & 5.00 & 3.4 & 1.06 \\
\hline $\begin{array}{l}\text { Don't know how to write the topic sentences for body } \\
\text { paragraphs }\end{array}$ & 1.00 & 5.00 & 3.4 & 1.01 \\
\hline Don't know how to write a thesis statement & 1.00 & 5.00 & 3.5 & .95 \\
\hline $\begin{array}{l}\text { Lack of ideas to illustrate or to explain for the }{ }_{44} \\
\text { supporting ideas }\end{array}$ & 1.00 & 5.00 & 3.8 & .84 \\
\hline Study in a large size class & 1.00 & 5.00 & 3.3 & .91 \\
\hline
\end{tabular}




\section{Second -Year English Majored Students' Perception of Possible Problems in Writing Essays}

The results about miscellaneous difficulties such as lacking ideas, lacking writing development skills, not knowing how to write a thesis statement, not feeling interested in the topics, and not knowing how to write the topic sentences for body paragraphs are found align with prior studies (Alfaki, 2015; Belkhir \& Benyelles, 2017; Ariyanti \& Firtriana, 2017).

\section{Solutions to tackle the problems}

The questionnaire also explored some solutions that the student participants proposed. These are thirteen solutions were proposed and mainly suggested to the teachers and the students themselves. The data are displayed in Table 7 below.

Table 7. Solutions proposed to tackle essay writing difficulties

\begin{tabular}{|c|c|c|c|c|c|}
\hline & $\mathrm{N}$ & Min & Max & Mean & S.D \\
\hline I should try to use various vocabulary & 44 & 1.00 & 5.00 & 4.2 & .82 \\
\hline I should avoid using conversational and informal words & 44 & 1.00 & 5.00 & 3.8 & .91 \\
\hline $\begin{array}{l}\text { I should use English-English dictionaries } \\
\text { spellcheckers }\end{array}$ & 44 & 2.00 & 5.00 & 4.1 & .71 \\
\hline I should improve my vocabulary in the different fields & 44 & 2.00 & 5.00 & 4.2 & .77 \\
\hline I should make an outline before writing essays & 44 & 2.00 & 5.00 & 4.0 & .92 \\
\hline I should build writing habits & 44 & 1.00 & 5.00 & 3.9 & .85 \\
\hline I should get peer feedback & 44 & 1.00 & 5.00 & 3.7 & .76 \\
\hline I should spend some time for free writing & 44 & 2.00 & 5.00 & 4.0 & .76 \\
\hline I should self-edit before submitting & 44 & 1.00 & 5.00 & 3.7 & .85 \\
\hline $\begin{array}{l}\text { Teachers should give more grammar courses for English } \\
\text { majors }\end{array}$ & 44 & 2.00 & 5.00 & 3.7 & .82 \\
\hline $\begin{array}{l}\text { Teachers need to give more feedbacks on students' } \\
\text { writing pieces }\end{array}$ & 44 & 2.00 & 5.00 & 3.9 & .79 \\
\hline $\begin{array}{l}\text { Teachers should organize group work activities such as } \\
\text { group discussion, role-play, peer editing, and debate in } \\
\text { the teaching essay writing skills }\end{array}$ & 44 & 2.00 & 5.00 & 4.0 & .89 \\
\hline $\begin{array}{l}\text { Teachers should recommend materials and motivate } \\
\text { students to read }\end{array}$ & 44 & 1.00 & 5.00 & 4.0 & .83 \\
\hline
\end{tabular}

Regarding the solutions suggested to the students themselves, the participants claim they should improve their vocabulary in different fields $(\mathrm{M}=4.2, \mathrm{SD}=.76)$, try to use various kinds of vocabulary $(\mathrm{M}=4.2, \mathrm{SD}=.81)$, use English-English dictionaries or spellcheckers $(M=4.1, S D=.71)$, spend some time for free writing $(M=4.0, S D=.76)$, and make an outline before writing essays $(\mathrm{M}=4.0, \mathrm{SD}=.91)$. Additionally, the results indicated that building writing habits $(\mathrm{M}=3.9, \mathrm{SD}=.85)$ and avoiding using spoken language $(\mathrm{M}=3.8, \mathrm{SD}=.91)$ can make their writing pieces better. Furthermore, getting peer feedback $(\mathrm{M}=3.7, \mathrm{SD}=.76)$ and selfediting writing before submitting $(\mathrm{M}=3.7, \mathrm{SD}=.85)$ are other ways the participants think it can lead them to success in writing essays.

Regarding their teachers, they expect their teachers recommend some relevant reading materials and motivate them to read $(\mathrm{M}=4.0, \mathrm{SD}=.83)$. It means that they believe there is a relationship between reading and writing skills. They also highly perceive that organizing group work activities $(\mathrm{M}=4.0, \mathrm{SD}=.89)$ could tackle their problems. Last but not least, the participants also need their teachers to give more feedbacks on their writing pieces $(\mathrm{M}=3.9, \mathrm{SD}=.79)$ and provide more grammar courses for English majors $(\mathrm{M}=3.7, \mathrm{SD}=.82)$.

\section{Interview results}

The results from the interview again confirmed what was found in the questionnaire. They reported some opinions which were also found from the quantitative data. However, the informal talks with the interviewees gave a clear picture of difficulties encountered by English major students. For instance, they said that they followed the writing process toughed by their teachers when writing and made an outline before writing. They believed that it is only enough time for practicing writing skills, they needed more time for their teachers to give feedback on their mistakes. Additionally, the participants admitted that writing the introduction and the body paragraphs for the essays is difficult for them. Furthermore, they reported that vocabulary and grammar are two language elements that trouble them much. It can be explained that the students seldom read other reading materials besides their course books. It is seen that less reading practice may be the reason which caused these students lack vocabularies to express their ideas, have no ideas to write in their writing pieces. Lastly, the participants also proposed some solutions which they strongly believe to tackle their problems in writing English essays. Once again, the findings from the interviews coincided with what was explored 


\section{Second -Year English Majored Students' Perception of Possible Problems in Writing Essays}

from the questionnaire. The solutions mainly regard to their teachers and themselves. For examples, the participants expected their teachers to give more helpful comments and interesting activities to motivate them in writing lessons. Wishing to be recommended some appropriate reading materials and having more grammar courses are two other expectations. Regarding the students themselves, they also think that they need to form reading habits so that their knowledge of grammar and vocabulary will be enhanced. They also stated that self-editing should be done before submitting to their teachers.

\section{CONCLUSIONS AND RECOMMENDATIONS Conclusions}

This present study mainly aimed to survey perception of second-year English majors' difficulties and their proposed solutions solving their problems. Forty-four second-year students majoring in English of English Department were invited to complete the questionnaire and a group of five students randomly selected to respond to the interview questions. The research results revealed some data which could answer the two research questions.

The first objective of the study was to investigate difficulties students face in writing essays. Based on the findings of this study, it established that second-year English majors faced four main difficulties in writing essays including linguistic, psychological, cognitive, and miscellaneous difficulties. The findings also revealed that the majority of second-year English major encountered difficulties in vocabulary and grammar when writing essays comprise having limited vocabulary, choosing the incorrect words, translating first language, and using informal language, wrong structure, and simple structure. Other common difficulties challenges revealed include: lacking topical knowledge, being under a lot of stress, not feeling self-confident about writing skills, being under time pressure, not having motivation and many ideas to write, lacking ideas to illustrate or explain for the supporting ideas.

The second objective of the study was to determine solutions from students proposed to overcome their own difficulties. The study findings show that some solutions for second-year English majors following as improving grammar, expanding vocabulary, using various vocabularies, reading various materials, building writing habit, and editing writing products before submitting. Besides, they want their teachers to give more exercises as well as helpful comments, interesting activities, recommend materials, and give them more grammar courses.

\section{Recommendations}

From what was explored in study, the researchers would like to suggest some recommendations for learners as well as for teachers in charge of writing lessons.

To the students who have learned English as their major, there are some recommendations suggested. To overcome writing difficulties, learners of English language should improve vocabulary retention in different fields such as science, food, economy, sports, plan, etc. Trying to remember the spellings of the words so that they could avoid spelling mistakes. Additionally, students should spend some time on free writing to build their own writing habits. When producing essays, they should try to use various vocabularies which could help them avoid repetition. When receiving higher scores in writing, they will be more confident and find interested in writing. Furthermore, English-English dictionary is highly recommended when they need to look up meanings and spellings. In fact, using English-English dictionary undoubtedly helps students learn more words. Besides, they also need to avoid using spoken language in writing academic essays. Self-editing before submitting and getting peer feedbacks are two ways that students can employ to reduce their mistakes in writing.

To the teachers who are in charge of delivering writing courses, they should recommend some relevant materials to the writing topics and motivate students to have extensive reading. In class, they should organize group work activities to stimulate their writing aspiration. Some more grammar courses could be provided to help the students use grammatical structures more effectively. Importantly, teachers need to give feedbacks on the students' writing pieces in time and assist them to improve their writing skills.

\section{REFERENCES}

1) Alfaki, I. (2015). University Students' Writing Problems: Diagnosis \& Remedy. International Journal of English Language Teaching, 3(3), 40-52.

2) Al-Mukdad (2019. Investigating English Academic Writing Problems Encountered by Arab International University Students. Theory and Practice in Language Studies, Vol. 9, No. 3, pp. 300-306.

3) Ariyanti, A \& Firtriana, R. (2017). ELF Students' Difficulties and Needs in Essay Writing. Atlantis Press, 158(28).

4) Belkhir, A \& Benyelles, R. (2017). Identifying EFL Learners Essay Writing Difficulties and Sources: A Move toward Solution the Case of Second Year EFL Learners at Tlemcen University. International Journal of Learning, Teaching and Educational Research, 16, 80-88.

5) Bowker, N. (Ed.). (2007). Academic Writing: A Guide to Tertiary Level Writing. New Zealand: Student Learning Development Services. 


\section{Second -Year English Majored Students' Perception of Possible Problems in Writing Essays}

6) Byrne, D. (1988). Teaching Writing Skills (Longman handbook for language teacher) (New ed.). (Byrne, Ed.) London, United Kingdom: Pte Ltd.

7) Hoang, V. V. (2018). The Current Situation and the Teaching of English in Vietnam. University of Languages and International Studies, Hanoi.

8) Ivanic, R. (1988). Writing and Identity The discoursal construction of identity in academic writing.

9) Mehrabi, N. (2014). The Effect of Second Language Writing Ability on First Language Writing Ability. Theory \& Practice in Language Studies, 4(8)

10) Nadjette, B. (2016). The Main Psychological Factors Affecting EFL Learners' Academic Writing. MA, Biskra University, Department of Foreign Languages, Biskra.

11) Nordquist, R. (2017). Writing. Retrieved from ThoughtCo.: https://www.thoughtco.com/writing-definition-1692616

12) Rahmatunisa, W. (2014). PROBLEMS FACED BY INDONESIAN EFL LEARNERS. Journal of English Education, III (1).

13) Siddiqi. (2007). The Difference Between Formal and Informal Writing. Ezine Article.

14) Solikah, I. (2017). Linguistic Problems in English Essay by EFL Students. Center of Language and Culture Studies, Surakarta, Indonesia, II (1). 